\title{
The oxygen-independent metabolism of cyclic monoterpenes in Castellaniella defragrans 65Phen
}

Jan Petasch', Eva-Maria Disch', Stephanie Markert ${ }^{2,4}$, Dörte Becher ${ }^{2,5}$, Thomas Schweder ${ }^{2,4}$, Bruno Hüttel ${ }^{3}$, Richard Reinhardt ${ }^{3}$ and Jens Harder ${ }^{1^{*}}$

\begin{abstract}
Background: The facultatively anaerobic betaproteobacterium Castellaniella defragrans 65Phen utilizes acyclic, monocyclic and bicyclic monoterpenes as sole carbon source under oxic as well as anoxic conditions. A biotransformation pathway of the acyclic $\beta$-myrcene required linalool dehydratase-isomerase as initial enzyme acting on the hydrocarbon. An in-frame deletion mutant did not use myrcene, but was able to grow on monocyclic monoterpenes. The genome sequence and a comparative proteome analysis together with a random transposon mutagenesis were conducted to identify genes involved in the monocyclic monoterpene metabolism. Metabolites accumulating in cultures of transposon and in-frame deletion mutants disclosed the degradation pathway.
\end{abstract}

Results: Castellaniella defragrans 65Phen oxidizes the monocyclic monoterpene limonene at the primary methyl group forming perillyl alcohol. The genome of $3.95 \mathrm{Mb}$ contained a $70 \mathrm{~kb}$ genome island coding for over 50 proteins involved in the monoterpene metabolism. This island showed higher homology to genes of another monoterpene-mineralizing betaproteobacterium, Thauera terpenica $58 \mathrm{Eu}^{\top}$, than to genomes of the family Alcaligenaceae, which harbors the genus Castellaniella. A collection of 72 transposon mutants unable to grow on limonene contained 17 inactivated genes, with 46 mutants located in the two genes $\mathrm{ctm} A B$ (cyclic terpene metabolism). CtmA and $\mathrm{ctmB}$ were annotated as FAD-dependent oxidoreductases and clustered together with $c t m E$, a $2 F e-2 S$ ferredoxin gene, and ctmF, coding for a NADH:ferredoxin oxidoreductase. Transposon mutants of ctmA, $B$ or $E$ did not grow aerobically or anaerobically on limonene, but on perillyl alcohol. The next steps in the pathway are catalyzed by the geraniol dehydrogenase GeoA and the geranial dehydrogenase GeoB, yielding perillic acid. Two transposon mutants had inactivated genes of the monoterpene ring cleavage ( $m r c)$ pathway. 2-Methylcitrate synthase and 2-methylcitrate dehydratase were also essential for the monoterpene metabolism but not for growth on acetate.

Conclusions: The genome of Castellaniella defragrans 65Phen is related to other genomes of Alcaligenaceae, but contains a genomic island with genes of the monoterpene metabolism. Castellaniella defragrans 65Phen degrades limonene via a limonene dehydrogenase and the oxidation of perillyl alcohol. The initial oxidation at the primary methyl group is independent of molecular oxygen.

Keywords: Monoterpene, Isoprenoids, Biodegradation, Limonene, Phellandrene

\section{Background}

Monoterpenes are structurally diverse secondary metabolites of plants. The volatile branched-chain $\mathrm{C}_{10}$ hydrocarbons are major constituents of essential oils and are also known to attract pollinators [1]. Monoterpenes with their characteristic scent possess antimicrobial and anti-herbivore properties and are added to various foods,

\footnotetext{
* Correspondence: jharder@mpi-bremen.de

'Department of Microbiology, Max Planck Institute for Marine Microbiology, Celsiusstraße 1, Bremen D-28359, Germany

Full list of author information is available at the end of the article
}

cosmetics or household products as flavor or antimicrobial agents [2].

Microbes use monoterpenes as carbon and energy source. The capability to transform monoterpenes is widespread among bacteria and fungi [3]. Already in the 1960s, the aerobic metabolism of several monoterpenes (limonene and $\alpha$-pinene) was described for soil pseudomonads and the fungus Aspergillus niger [4]. Pseudomonads also use the acyclic citronellol $[5,6]$ and Pleurotus sapidus was found to transform the bicyclic $\Delta^{3}$-carene 
[7]. Limonene may be an intermediate in the metabolism of bicyclic [8] and acyclic monoterpenes [9].

The monocyclic limonene (4-isopropenyl-1-methylcyclohexene) is one of the most common monoterpenes [10]. Several limonene biotransformation pathways with molecular oxygen as co-substrate were described for aerobic microorganisms [11,12]: (I) the oxidation at the primary methyl group to perillyl alcohol and further oxidation; (II) the epoxidation of the ring double bond and formation of a diol; (III) the ring oxidation at the C3 position forming carveol or at the C6 position forming isopiperitenol, and (IV) the epoxidation of the double bond at the isopropenyl group. All these reactions are catalyzed by cytochrome P450 monooxygenases [13]. Alternative initial reactions involve the addition of water to a double bond. The hydration of limonene to $\alpha$-terpineol was reported for bacterial and fungal species [14]. Anoxic conditions seem to increase the transformation rate [15] and cofactor-independent hydratases were identified to catalyze the reaction $[16,17]$. The further degradation of $\alpha$-terpineol via oleuropeic acid or borneol is again dependent on molecular oxygen as co-substrate [18].

A microbial monoterpene mineralization to carbon dioxide in the absence of molecular oxygen was first observed with the enrichment and isolation of denitrifying strains [19-21]. One of these strains, Castellaniella defragrans 65Phen isolated with $\alpha$-phellandrene, is able to use various acyclic, monocyclic and bicyclic monoterpenes as sole carbon and energy source. Cyclic monoterpenes require a $\mathrm{sp}^{2}$-hybridized $\mathrm{C} 1$-atom as precondition for mineralization [22]. Initial metabolite studies showed the formation of geranic acid from $\beta$-myrcene in cell-free extracts [23]. A pathway from the acyclic monoterpene $\beta$-myrcene to geranic acid was identified. $\beta$-Myrcene is enantiospecifically hydrated to $(S)-(+)$-linalool and further isomerized to geraniol by the linalool dehydrataseisomerase (LDI) $[24,25]$. The $\mathrm{NAD}^{+}$-dependent geraniol dehydrogenase GeoA and geranial dehydrogenase GeoB oxidize geraniol to geranial and further to geranic acid (published as GeDH and $\mathrm{GaDH}$ ) [26]. With the development of a genetic system for $C$. defragrans 65Phen, an in-frame deletion mutant with an inactivated $l d i$ gene showed no growth with the acyclic $\beta$-myrcene, but grew like the wild type on limonene or $\alpha$-phellandrene [27].

In this publication, we report our search for an anaerobic pathway for cyclic monoterpene degradation in Castellaniella defragrans 65Phen. On the basis of the genome, expressed proteins were extracted from $\alpha$-phellandrene- and acetate-grown cultures and identified by two-dimensional gel electrophoresis coupled to MALDI-TOF-MS as well as membrane protein-enriched LC-ESI-MS/MS. A random transposon mutagenesis with a Mini-Tn5 transposon identified genes essential for the growth on cyclic monoterpenes. Metabolites formed in cultures of several genotypes were identified by GC-MS. The observations were integrated to develop a putative degradation pathway.

\section{Results and discussions}

\section{The genome of Castellaniella defragrans}

The closed genome of Castellaniella defragrans 65Phen has $3,952,818 \mathrm{bp}$ and an overall $\mathrm{G}+\mathrm{C}$ content of $68.9 \%$. 3616 protein-coding open reading frames (ORFs), 45 transfer RNA genes and 2 ribosomal RNA operons, comprising 5S, $16 \mathrm{~S}$ and $23 \mathrm{~S}$ ribosomal RNA genes, were detected in the genome. $C$. defragrans 65Phen has complete sets of genes for the citrate cycle, aerobic respiration and denitrification including nitrite reductase nirK and both quinol-dependent nitrite oxide reductase and cytochrome $\mathrm{C}$-dependent nitrite oxide reductase type nor $B$. The degradative pathways matched the observed substrate utilization [21]. The lack of growth on sugars coincided with the absence of a 6-phosphofructokinase, thus the glycolysis pathway was incomplete. The biosynthesis of sugars on anabolic pathways is ensured by a fructose-1,6-bisphosphatase type I. The comparison with other genomes revealed a high similarity to related Alcaligenaceae species, e.g., Bordetella pertussis Tohama I (average nucleotide identity (ANI) 82.1\%) or Pusillimonas sp. T7-7 (ANI 80.7\%). C. defragrans 65Phen shares 1954 ORFs (54\%) with the published genome of Bordetella pertussis Tohama I (Acc. no. NC_002929). In these genes the average amino acid identity was $62 \%$.

An exception was an island of $70 \mathrm{~kb}$ DNA located from base 3026577 to 3096437 (Table 1). The island is flanked upstream by a transposable element and downstream by a cluster for the degradation of amino acids. The majority of genes in the island are most similar to betaproteobacterial genes outside the Alcaligenaceae. The island includes the genes for the initial myrcene transformation, $l d i$ for the linalool dehydratase-isomerase, $g e o A$ for the geraniol dehydrogenase and $g e o B$ for the geranial dehydrogenase, and the previously published contig derived from fosmids (Acc. no. FR669447). The predicted proteins (Tab. 1) resemble proteins of the monoterpenemineralizing strains, Thauera terpenica $58 \mathrm{Eu}^{\mathrm{T}}$ [20] and Pseudomonas sp. 19-rlim [28], as well as of Azoarcus strains, which have not been tested for monoterpene degradation. Thauera and Azoarcus are Rhodocyclales with a well-established capacity to mineralize aromatic hydrocarbons [29]. Pseudomonas sp. 19-rlim belongs to the gammaproteobacterial Pseudomonadaceae which degrade a wide range of hydrophobic substances [30]. Many predicted proteins in the island were annotated as betaoxidation pathway-related enzymes and as a transporter of hydrophobic substances. 
Table 1 Genes of the genome island and assigned functions in the metabolism of monoterpenes in Castellaniella defragrans 65Phen

\begin{tabular}{|c|c|c|c|c|c|c|c|}
\hline \multirow[t]{2}{*}{ Protein_id } & \multirow{2}{*}{$\begin{array}{l}\text { Proteine } \\
\text { detection } \\
\text { method }^{\mathrm{a}}\end{array}$} & \multirow{2}{*}{$\begin{array}{c}2 \mathrm{D} \text { fold } \\
\text { change/LC } \\
\text { enrichment } \\
\text { level }^{\mathrm{b}}\end{array}$} & \multirow[t]{2}{*}{ Gene annotation } & \multicolumn{4}{|c|}{ Related gene product } \\
\hline & & & & E value & $\%$ identity & Organism & Accession no. \\
\hline CDM25240 & n.d. & n.d. & Hypothetical protein & $4 \mathrm{E}-60$ & 59 & Thauera terpenica 58Eu & EPZ16239 \\
\hline CDM25241 & LC & ++ & $\begin{array}{l}\text { Acyl-CoA dehydrogenase } \\
\text { protein }\end{array}$ & 0.0 & 82 & Thauera terpenica 58Eu & EPZ16240 \\
\hline CDM25242 & LC & 0 & Molybdopterin-binding OR & $3 \mathrm{E}-70$ & 74 & Thauera terpenica 58Eu & EPZ16227 \\
\hline CDM25243 & n.d. & n.d. & Tyrosine/serine phosphatase & $1 \mathrm{E}-58$ & 48 & Thauera linaloolentis 47Lol & ENO83508 \\
\hline CDM25244 & LC & 0 & 2,4-dienoyl-CoA reductase & 0.0 & 87 & Thauera terpenica 58Eu & EPZ16243 \\
\hline CDM25245 & n.d. & n.d. & NADH:flavin oxidoreductase & $1 \mathrm{E}-179$ & 68 & Thauera terpenica 58Eu & EPZ16244 \\
\hline CDM25246 & 2D/LC & $3.0 /++$ & $\begin{array}{l}\text { 3-hydroxyacyl-CoA } \\
\text { dehydrogenase }\end{array}$ & $5 \mathrm{E}-167$ & 82 & Azoarcus sp. KH32C & YP_007598290 \\
\hline CDM25247 & n.d. & n.d. & IS4 family transposase & 0.0 & 63 & Thiomonas sp. FB-6 & WP_018915433 \\
\hline CDM25248, MrCH & n.d. & n.d. & MaoC-like dehydratase & $2 \mathrm{E}-36$ & 62 & Azoarcus sp. $\mathrm{KH} 32 \mathrm{C}$ & YP_007598291 \\
\hline CDM25249, MrcG & n.d. & n.d. & MaoC-like dehydratase & $6 \mathrm{E}-50$ & 67 & Thauera terpenica 58Eu & EPZ16257 \\
\hline CDM25250, MrcF & LC & ++ & Perillyl-CoA hydratase & 0.0 & 58 & Thauera terpenica 58Eu & EPZ16258 \\
\hline CDM25251, MrcE & 2D/LC & $18 /++$ & $\begin{array}{l}\text { 4-isopropenyl-2-oxo-cyclohexane- } \\
\text { 1-carboxyl-CoA hydrolase }\end{array}$ & $4 \mathrm{E}-167$ & 88 & Azoarcus sp. $\mathrm{KH} 32 \mathrm{C}$ & YP_007598294 \\
\hline CDM25252, MrcD & 2D/LC & $3.0 /++$ & $\begin{array}{l}\text { 2-hydroxy-4-isopropenyl- } \\
\text { cyclohexane-1-carboxyl-CoA } \\
\text { dehydrogenase }\end{array}$ & $1 \mathrm{E}-153$ & 85 & Azoarcus sp. KH32C & YP_007598295 \\
\hline CDM25253, MrcC & $2 \mathrm{D}$ & 2,3 & 2,4-dienoyl reductase & 0.0 & 86 & Thauera terpenica 58Eu & EPZ16261 \\
\hline CDM25254, MrcB & LC & ++ & Acyl-CoA dehydrogenase & 0.0 & 90 & Azoarcus toluclasticus & WP_018990727 \\
\hline CDM25255, MrcA & LC & ++ & Oxidoreductase, FAD-binding & 0.0 & 73 & Azoarcus toluclasticus & WP_018990723 \\
\hline CDM25256 & 2D/LC & $19 /++$ & (R)-specific enoyl-CoA hydratase & $1 \mathrm{E}-88$ & 85 & Thauera terpenica 58Eu & EPZ15051 \\
\hline CDM25257 & LC & 0 & Citrate lyase & $6 \mathrm{E}-141$ & 73 & Thauera terpenica 58Eu & EPZ15052 \\
\hline CDM25258 & LC & ++ & Acyl-CoA dehydrogenase & 0.0 & 92 & Thauera terpenica 58Eu & EPZ15053 \\
\hline CDM25259 & LC & ++ & RND efflux transporter & 0.0 & 62 & Thauera terpenica 58Eu & EPZ15054 \\
\hline CDM25260 & LC & ++ & RND efflux transporter & 0.0 & 80 & Thauera terpenica 58Eu & EPZ15055 \\
\hline CDM25261 & LC & ++ & RND efflux transporter & $4 \mathrm{E}-142$ & 68 & Thauera terpenica 58Eu & EPZ15056 \\
\hline CDM25262 & LC & ++ & RND efflux transporter & 0.0 & 81 & Thauera terpenica 58Eu & EPZ15057 \\
\hline CDM25263 & LC & ++ & Acetoacetyl-CoA synthetase & 0.0 & 84 & Thauera terpenica 58Eu & EPZ15058 \\
\hline CDM25264 & n.d. & n.d. & Enoyl-CoA hydratase & $9 \mathrm{E}-136$ & 76 & Thauera terpenica 58Eu & EPZ15059 \\
\hline CDM25265, GeoC & LC & ++ & Perillate-CoA ligase & 0.0 & 71 & Thauera terpenica 58Eu & EPZ15060 \\
\hline CDM25266 & LC & 0 & Hypothetical protein & 4,3 & 52 & $\begin{array}{l}\text { Fusarium graminearum } \\
\mathrm{PH}-1\end{array}$ & XP_382023 \\
\hline CDM25267, GeoA & 2D/LC & $42 /++$ & Geraniol dehydrogenase & 0.0 & 84 & Thauera terpenica 58Eu & EPZ14350 \\
\hline CDM25268 & LC & ++ & Hypothetical protein & $8 \mathrm{E}-117$ & 74 & Thauera terpenica 58Eu & EPZ14349 \\
\hline CDM25269 & n.d. & n.d. & Hypothetical protein & $2 \mathrm{E}-97$ & 69 & Thauera terpenica 58Eu & EPZ14348 \\
\hline CDM25270 & n.d. & n.d. & Hypothetical protein & $6 \mathrm{E}-32$ & 66 & Thauera terpenica 58Eu & EPZ14347 \\
\hline CDM25271 & n.d. & n.d. & Thioesterase & $2 E-33$ & 46 & $\begin{array}{l}\text { Magnetospirillum } \\
\text { magneticum }\end{array}$ & YP_420191 \\
\hline CDM25272, LDI & LC & ++ & LDI precursor protein & $8 \mathrm{E}-14$ & 25 & $\begin{array}{l}\text { Stereum hirsutum } \\
\text { FP-91666 SS1 }\end{array}$ & EIM80109 \\
\hline CDM25273 & n.d. & n.d. & Hypothetical protein & $5 E-85$ & 43 & Gordonia paraffinivorans & WP_006900876 \\
\hline CDM25274 & n.d. & n.d. & Hypothetical protein & $5 \mathrm{E}-07$ & 30 & Gordonia paraffinivorans & WP_006900845 \\
\hline CDM25275 & LC & ++ & Acyl-CoA dehydrogenase & $4 \mathrm{E}-106$ & 54 & Azoarcus toluclasticus & WP_018990670 \\
\hline
\end{tabular}


Table 1 Genes of the genome island and assigned functions in the metabolism of monoterpenes in Castellaniella defragrans 65Phen (Continued)

\begin{tabular}{|c|c|c|c|c|c|c|c|}
\hline CDM25276 & n.d. & n.d. & Hypothetical protein & $4 \mathrm{E}-40$ & 40 & Glaciecola punicea & WP_006005307 \\
\hline CDM25277 & n.d. & n.d. & Hypothetical protein & $5 E-21$ & 58 & Pseudomonas sp. 19-rlim & AEO27370 \\
\hline CDM25278 & n.d. & n.d. & Hypothetical protein & $1 \mathrm{E}-69$ & 62 & Pseudomonas sp. 19-rlim & AEO27371 \\
\hline CDM25279 & LC & ++ & Hypothetical protein & $1 \mathrm{E}-120$ & 68 & Pseudomonas sp. 19-rlim & AEO27372 \\
\hline CDM25280 & n.d. & n.d. & MarR transcriptional regulator & 7E-81 & 83 & Thauera terpenica $58 \mathrm{Eu}$ & EPZ16291 \\
\hline CDM25281, GeoB & 2D/LC & $15 /++$ & Geranial dehydrogenase & 0.0 & 91 & Thauera terpenica $58 \mathrm{Eu}$ & EPZ16290 \\
\hline CDM25282 & LC & ++ & Acyl-CoA dehydrogenase & 0.0 & 89 & Thauera terpenica $58 \mathrm{Eu}$ & EPZ16289 \\
\hline CDM25283 & n.d. & n.d. & $\begin{array}{l}\text { LuxR family transcriptional } \\
\text { regulator }\end{array}$ & 0.0 & 59 & Thauera terpenica $58 \mathrm{Eu}$ & EPZ16271 \\
\hline CDM25284, CtmG & LC & ++ & Hypothetical protein & $5 E-35$ & 39 & Azoarcus sp. KH32C & YP_007598506 \\
\hline CDM25285, CtmF & LC & ++ & NADH:ferredoxin oxidoreductase & $4 \mathrm{E}-147$ & 56 & Caulobacter sp. AP07 & WP_007674692 \\
\hline CDM25286, CtmE & $2 \mathrm{D}$ & $6.3 /++$ & Ferredoxin, $2 \mathrm{Fe}-2 \mathrm{~S}$ & $1 \mathrm{E}-32$ & 50 & $\begin{array}{l}\text { Caulobacter crescentus } \\
\text { CB15 }\end{array}$ & NP_422318 \\
\hline CDM25287, CtmD & n.d. & n.d. & Hypothetical protein & 4,1 & 38 & Ochrobactrum sp. CDB2 & WP_007881652 \\
\hline CDM25288, CtmC & n.d. & n.d. & Hypothetical protein & 2,3 & 33 & Bombus impatiens & XP_003489707 \\
\hline CDM25289, CtmB & 2D/LC & $3.4 /++$ & Limonene dehydrogenase & $4 \mathrm{E}-131$ & 41 & $\begin{array}{l}\text { Deltaproteobacterium } \\
\text { NaphS2 }\end{array}$ & WP_006422074 \\
\hline CDM25290, CtmA & LC & ++ & Limonene dehydrogenase & $5 E-57$ & 30 & $\begin{array}{l}\text { Deltaproteobacterium } \\
\text { NaphS2 }\end{array}$ & WP_006422074 \\
\hline CDM25291 & LC & ++ & Acetyl-CoA acetyltransferase & 0.0 & 79 & Thauera terpenica $58 \mathrm{Eu}$ & EPZ16237 \\
\hline CDM25292 & LC & 0 & MarR transcriptional regulator & $2 \mathrm{E}-76$ & 77 & Thauera terpenica $58 \mathrm{Eu}$ & EPZ16235 \\
\hline CDM25293 & n.d. & n.d. & Hypothetical protein & $4 \mathrm{E}-24$ & 56 & Thauera terpenica $58 \mathrm{Eu}$ & EPZ16283 \\
\hline CDM25294 & LC & ++ & Hypothetical protein & $2 \mathrm{E}-83$ & 68 & Thauera terpenica $58 \mathrm{Eu}$ & EPZ16282 \\
\hline CDM25295 & n.d. & n.d. & Hypothetical protein & $6 \mathrm{E}-155$ & 76 & Thauera terpenica $58 \mathrm{Eu}$ & EPZ16281 \\
\hline CDM25296 & n.d. & n.d. & MarR transcriptional regulator & $5 E-94$ & 81 & Thauera terpenica $58 \mathrm{Eu}$ & EPZ16280 \\
\hline CDM25297 & n.d. & n.d. & Hypothetical protein & $2 \mathrm{E}-168$ & 72 & Thauera terpenica 58Eu & EPZ16232 \\
\hline CDM25298 & LC & ++ & Hypothetical protein & 0.0 & 72 & Thauera terpenica $58 \mathrm{Eu}$ & EPZ16231 \\
\hline CDM25299 & LC & ++ & Acetyl-CoA acetyltransferase & 0.0 & 90 & Thauera terpenica $58 \mathrm{Eu}$ & EPZ16230 \\
\hline CDM25300 & n.d. & n.d. & Acetyl-CoA hydrolase/transferase & 0.0 & 74 & Thauera terpenica 58Eu & EPZ16229 \\
\hline CDM25301 & LC & ++ & Electron transfer flavoprotein & $7 E-133$ & 78 & Thauera terpenica $58 \mathrm{Eu}$ & EPZ16226 \\
\hline CDM25302 & n.d. & n.d. & Electron transfer flavoprotein & $7 E-160$ & 76 & Azoarcus sp. KH32C & YP_007552025 \\
\hline
\end{tabular}

${ }^{\mathrm{a}} 2 \mathrm{D}$, identified with 2D-SDS-PAGE and MALDI-TOF-MS; LC, identified with LC-ESI-MS/MS.

${ }^{b}++$ peptides only identified in a-phellandrene fraction, + increase in a-phellandrene fraction, 0 ratio remained unchanged.

\section{The proteome of monoterpene utilization}

The soluble protein fractions of bacteria grown on acetate or on $\alpha$-phellandrene were analyzed by two-dimensional gel electrophoresis, followed by enzymatic digest and MALDI-TOF mass spectrometry. The enriched membrane protein fractions were analyzed by one-dimensional gel electrophoresis, enzymatic digest and LC-ESI-MS/MS. 234 and 851 individual proteins of $C$. defragrans 65Phen were identified with 2D-SDS-PAGE separation and MALDITOF-MS, and with LC-ESI-MS/MS, respectively. The monoterpene proteome, defined as proteins induced in extracts of $\alpha$-phellandrene-grown cells in comparison to extracts of acetate-grown cells, included a total of 107 proteins, of which 28 proteins were identified by MALDITOF-MS and 97 proteins were identified by LC-ESI-MS/
MS, with an overlap of 18 proteins that were identified by both techniques (Additional file 1: Table S1). 32 of these proteins are encoded by genes in the island including the enzymes LDI, GeoA and GeoB. Among the $75 \alpha-$ phellandrene-induced proteins with a gene location outside of the island, $A B C$ transporter-associated proteins were highly up-regulated.

\section{Growth on oxidized limonene metabolites}

The geraniol dehydrogenase GeoA is an allyl-alcohol dehydrogenase with the highest catalytic activity on perillyl alcohol [26]. The high expression of GeoA and GeoB in $\alpha$-phellandrene-grown cells questioned the utilization of the cyclic monoterpene alcohol by $C$. defragrans. The strain 65Phen grew on perillyl alcohol, perillyl aldehyde 
and perillic acid (Figure 1B-D). During active denitrification, perillyl aldehyde accumulated transiently in the culture growing on perillyl alcohol (Figure 1B). Perillic acid accumulated in cultures growing on the alcohol and the aldehyde. When the electron acceptor nitrate was depleted, the cells disproportionated perillyl aldehyde into perillyl alcohol and perillyl acid (Figure 1B, C). During growth on limonene (Figure 1A), the perillyl derivatives were not detected suggesting a rate-limitation in the pathway by the initial limonene-transforming enzyme.

\section{Transposon insertion mutagenesis}

To identify the genes involved in monoterpene degradation, a random insertion mutagenesis with a mini-Tn5 transposon was performed according to Larsen et al. [31]. Insertion mutants of $C$. defragrans 65Phen were obtained on agar plates with a minimal medium and acetate and nitrate as carbon source and electron acceptor, respectively, and rifampicin and kanamycin as selective compounds. These colonies were transferred to acetate-free anoxic plates with nitrate and supplied with limonene via the gas phase. Six of 1000 insertion mutants revealed a lack of growth under these conditions.
Our collection of 72 mutant strains covered 46 unique insertion positions in 17 genes. The majority of insertions yielding a loss of function were in $\mathrm{ctm} A$. It was inactivated in 45 mutants at 22 different positions. The adjacent gene $\operatorname{ctmB}$ was inactivated thrice at different positions. Also a gene closely located, $c t m E$, was inactivated at two insertion sites. Five genes were present at least twice in the mutant collection, whereas nine other genes were present once. The five genes coded CDM25082, CDM25239, CDM25260, CDM25338 and CDM25923.

Anaerobic denitrifying growth of selected transposon mutants was tested in liquid culture (Table 2). All transposon mutants denitrified and grew with acetate in liquid culture. In liquid culture on limonene, four strains, the mutants of a putative transcriptional regulator (CDM25239), a putative inner membrane protein (CDM25338), a hypothetical protein (CDM25510) and a plasmid stability protein (CDM24643) grew similarly to the wild type in liquid culture. No colony formation on plates, but growth in liquid medium coincided with a reduced mass transfer limitation of limonene in liquid culture. Three mutant strains showed weak growth and ten mutant strains did not grow on limonene in liquid culture (Table 2). Additional growth
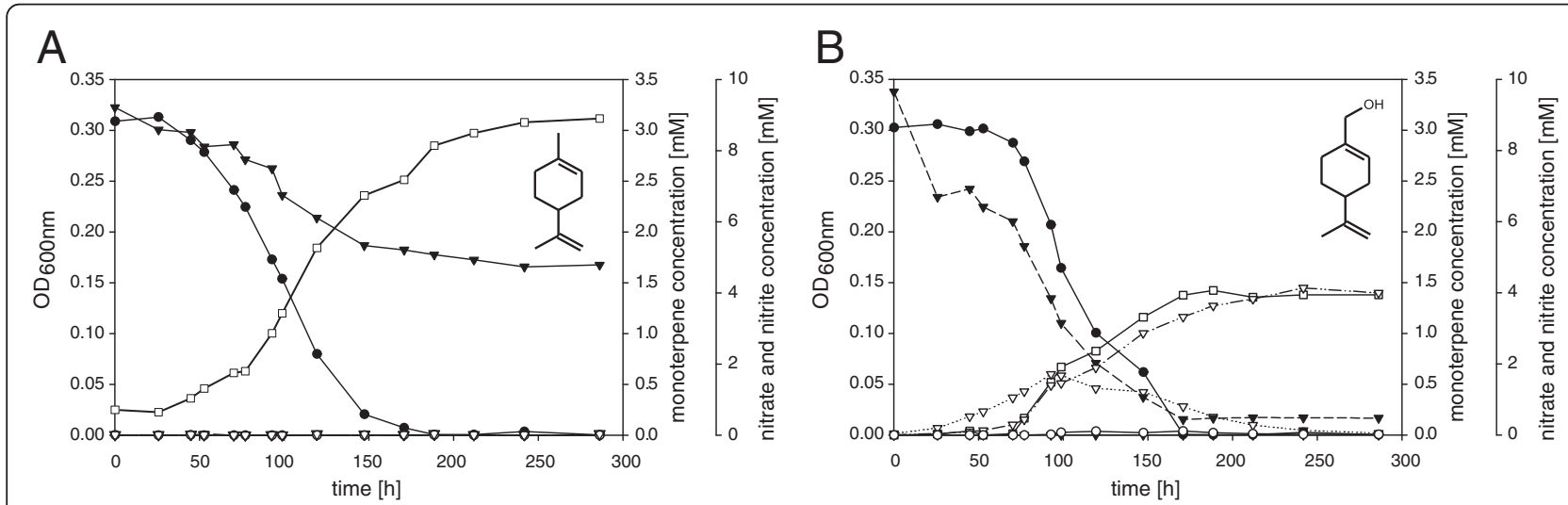

C

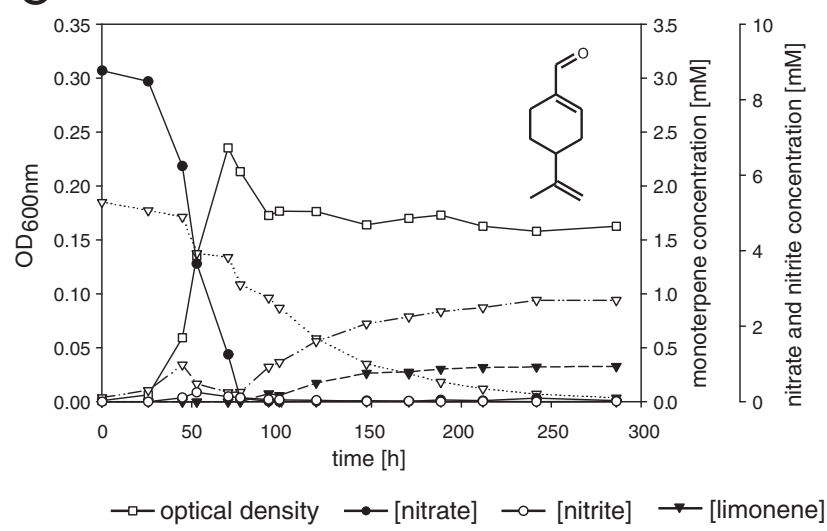

$\mathrm{D}$

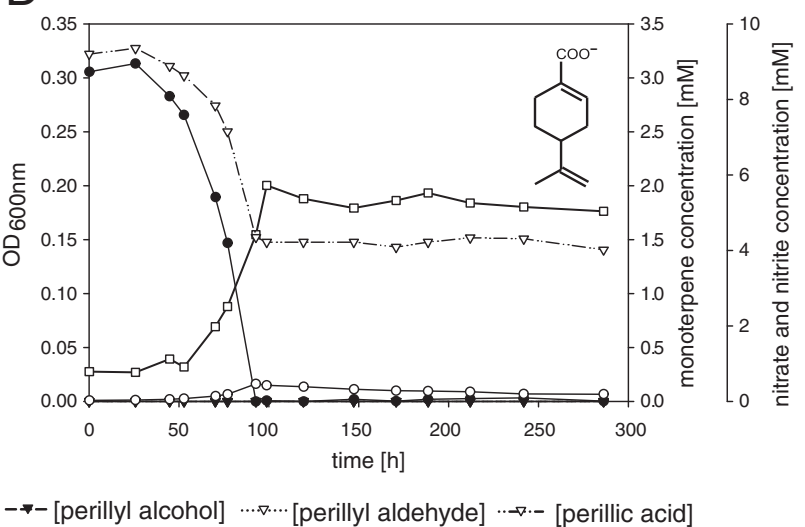

Figure 1 Anaerobic growth of C. defragrans 65Phen on limonene and putative metabolites. Limonene (A), perillyl alcohol (B), perillyl aldehyde (C) and perillic acid (D) were tested as growth substrate, each with a concentration of $3 \mathrm{mM}$ and nitrate limitation (10 mM). 
Table 2 Growth of Castellaniella defragrans 65Phen transposon insertion mutants in liquid medium

\begin{tabular}{|c|c|c|c|c|c|c|c|}
\hline \multirow{2}{*}{$\begin{array}{l}\text { Inactivated } \\
\text { gene }\end{array}$} & \multirow[t]{2}{*}{ Annotation } & \multirow{2}{*}{$\begin{array}{l}\text { Length } \\
\text { [b] }\end{array}$} & \multirow{2}{*}{$\begin{array}{c}\text { Insertion } \\
\text { positions [b] }\end{array}$} & \multicolumn{4}{|c|}{ Growth substrate $^{*}$} \\
\hline & & & & Acetate & Limonene & $\beta$-Myrcene & Further substrates \\
\hline \multicolumn{8}{|l|}{ Initial oxidation } \\
\hline CDM25290 CtmA & $\begin{array}{l}\text { Limonene dehydrogenase, } \\
\text { alpha subunit }\end{array}$ & 1698 & 133 & + & - & - & $\begin{array}{l}\text { Perillyl alcohol (+), a-phellandrene }(-) \text {, } \\
\text { a-pinene }(-), \beta \text {-pinene }(-)\end{array}$ \\
\hline CDM25290 CtmA & $\begin{array}{l}\text { Limonene dehydrogenase, } \\
\text { alpha subunit }\end{array}$ & 1698 & 1188 & + & - & - & $\begin{array}{l}\text { Perillyl alcohol }(+) \text {, a-phellandrene }(-) \text {, } \\
\text { a-pinene }(-), \beta \text {-pinene }(-)\end{array}$ \\
\hline CDM25289 CtmB & $\begin{array}{l}\text { Limonene dehydrogenase, } \\
\text { beta subunit }\end{array}$ & 1650 & 38 & + & - & - & $\begin{array}{l}\text { Perillyl alcohol (+), a-phellandrene }(-) \text {, } \\
\text { a-pinene }(-), \beta \text {-pinene }(-)\end{array}$ \\
\hline CDM25289 CtmB & $\begin{array}{l}\text { Limonene dehydrogenase, } \\
\text { beta subunit }\end{array}$ & 1650 & 559 & + & - & - & $\begin{array}{l}\text { Perillyl alcohol (+), a-phellandrene (-), } \\
\text { a-pinene }(-), \beta \text {-pinene (-) }\end{array}$ \\
\hline CDM25286 CtmE & Ferredoxin, $2 \mathrm{Fe}-2 \mathrm{~S}$ & 324 & 111 & + & - & - & $\begin{array}{l}\text { Perillyl alcohol }(+) \text {, a-phellandrene }(-), \\
\text { a-pinene }(-), \beta \text {-pinene }(-)\end{array}$ \\
\hline \multicolumn{8}{|c|}{ Ring cleavage and $\beta$-oxidation } \\
\hline CDM23589 & $\begin{array}{l}\text { Electron transfer flavoprotein: } \\
\text { ubiquinone oxidoreductase }\end{array}$ & 1647 & 138 & + & $(+)$ & $(+)$ & Perillic acid $((+))$ \\
\hline CDM25250 MrcF & Perillyl-CoA hydratase & 1239 & 18 & + & - & - & a-phellandrene (-) \\
\hline CDM25253 MrcC & 2,4-dienoyl-CoA reductase & 888 & 841 & + & - & - & a-phellandrene (-) \\
\hline CDM25297 & Hypothetical protein & 1023 & 34 & + & - & - & \\
\hline CDM258488 & Electron transfer protein & 888 & 385 & + & - & - & Perillic acid (-) \\
\hline CDM25923 & Enoyl-CoA hydratase & 777 & 461 & + & - & - & \\
\hline \multicolumn{8}{|l|}{ Methylcitrate cycle } \\
\hline CDM25082 & 2-methylcitrate dehydratase & 1452 & 262 & + & - & - & \\
\hline CDM25081 & 2-methylcitrate synthase & 1239 & -18 & + & $(+)$ & + & \\
\hline \multicolumn{8}{|l|}{ Other functions } \\
\hline CDM23676 & $\begin{array}{l}\text { Molybdenum transport } \\
\text { system protein }\end{array}$ & 865 & 47 & + & - & - & Perillyl aldehyde (-) \\
\hline CDM25260 & $\begin{array}{l}\text { RND efflux transporter, } \\
\text { periplasmic component }\end{array}$ & 1356 & 24 & + & $(+)$ & $(+)$ & Perillic acid $((+))$ \\
\hline
\end{tabular}

* + growth like wild type; - no growth; $(+)$ decreased growth rate and maximum density compared to wild type.

experiments showed that the genes $\operatorname{ctm} A, \operatorname{ctm} B$ or $c t m E$ were not required for growth on perillyl alcohol. This physiology was also observed in aerobic cultures growing in the absence of nitrate (Additional file 2: Figure S1). The three genes are part of an operon-like cluster which was named ctmABCDEFG, for cyclic terpene metabolismassociated genes (Table 1). Also other monoterpenes tested (Table 2) did not support growth of these three mutants.

\section{Metabolite formation from limonene}

To demonstrate the in vivo formation of perillyl alcohol from limonene, an in-frame deletion mutant of $g e o B$ was generated. The deletion of the alcohol dehydrogenase gene geo $A$ caused a decreased growth rate and biomass formation with several monoterpenes as growth substance. We attribute this residual growth with the expression of a second alcohol dehydrogenase in cells of the in-frame $\triangle g e o A$ mutant [27]. The deletion mutant $C$. defragrans 65 Phen $\triangle g e o B$ grew on acetate and perillic acid, but lacked the ability to grow on limonene, $\beta$ - myrcene, perillyl alcohol and perillyl aldehyde (data not shown). To analyze the metabolite formation, the mutant and for comparison the wild type were anaerobically cultured with $3 \mathrm{mM}(R)-(+)$-limonene and $20 \mathrm{mM}$ acetate as co-substrates in the presence of $20 \mathrm{mM}$ nitrate. To increase the mass transfer, the organic carrier phase 2,2,4,4,6,8,8-heptamethylnonane (HMN) - and with it the two-phase system - was replaced by $0.5 \% \mathrm{v} / \mathrm{v}$ Tween 20 in a homogeneous phase. In the early stationary phase after seven days, hydrophobic compounds were salted out and extracted with isopropanol. The metabolites in the isopropanol phase were analyzed stereospecifically by GC and GC-MS (Figure 2). (R)$(+)$-perillyl alcohol as well as $(R)-(+)$-perillyl aldehyde were not detected in an abiotic control without cells and in the culture of the wild type, but in the deletion mutant $\triangle g e o B$. This in vivo formation of $(R)-(+)$-perillyl alcohol from $(R)-(+)$-limonene suggested an oxidation of limonene at the methyl group as initial reaction of the degradation pathway. 


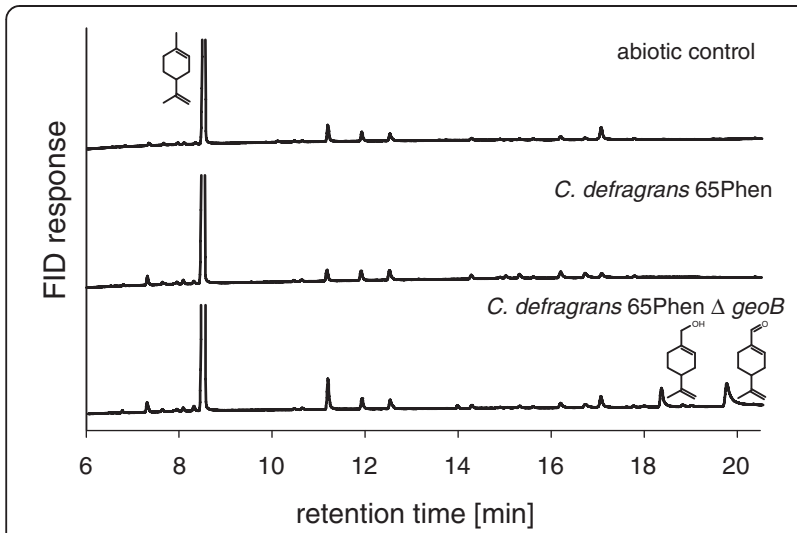

Figure $2 \mathrm{GC}$ chromatogram of metabolite accumulation.

Extracts of nitrate-limited cultures were obtained from the primary stationary phase of cultures grown with $20 \mathrm{mM}$ acetate as co-substrate and $3 \mathrm{mM}(R)-(+)$-limonene.

\section{Hypothetical pathway of limonene degradation based on genome, monoterpene proteome and the physiology of transposon mutants}

The genome island of $C$. defragrans 65Phen is related to genes of $T$. terpenica $58 \mathrm{Eu}^{\mathrm{T}}$ which also mineralizes cyclic monoterpenes anaerobically [21]. A related gene cluster from Pseudomonas sp. strain 19-rlim has been deposited, but not described (Genbank JN379031). Of these strains, only $C$. defragrans 65 Phen has the cyclic terpene metabolism cluster that contained two FAD-dependent oxidoreductases $(c t m A$ and $c t m B)$, a $2 \mathrm{Fe}-2 \mathrm{~S}$ ferredoxin $(c t m E)$ and a ferredoxin reductase $(c t m F)$ together with three hypothetical genes $(\operatorname{ctm} C D$ and $c t m G)$ and a putative transcriptional regulator of the luxR family. CtmA, B, E and $\mathrm{F}$ were up-regulated proteins in $\alpha$-phellandrenegrown cells, in comparison to acetate-grown cells. The other proteins of the cluster were not detected. The physiology of the transposon mutants in $\operatorname{ctm} A, \operatorname{ctm} B$ and $c t m E$ together with the formation of perillyl alcohol in cultures of the $\triangle g e o B$ mutant suggests that the Ctm subunits represent a novel enzyme for hydrocarbon activation, catalyzing the oxidation of a methyl group from limonene to the corresponding alcohol. More precisely, a methyl group of an allyl group is oxidized, as it was demonstrated that the carbon-carbon double bond is required for the metabolism [22]. So far, the activation of hydrocarbons in the absence of molecular oxygen is known to be catalyzed by glycine radical enzymes (alkanes, toluene) or molybdenum-containing enzymes (ethylbenzene, cholesterol) [29]. The Ctm enzyme seems to comprise a catalytic core of $\mathrm{CtmAB}$ and an electron transfer chain consisting of CtmEF. CtmAB are both annotated as FAD-dependent oxidoreductases, but have a low amino acid identity to each other (27\%). The domain structure of both oxidoreductases is similar to those of phytoene dehydrogenases (COG1233, E value of $1 \mathrm{e}^{-60}$ ) which introduce symmetrically double bonds at phytoene adjacent to existing carbon-carbon double bonds. This process is also an oxidation of the alkyl part of an allylic group. Oxidized dinucleotides like FAD were described as electron acceptors for bacterial phytoene dehydrogenases [32]. Among the COG1233 enzymes, CtmAB showed the largest gene identity to a putative oxidoreductase of the deltaproteobacterial obligate anaerobic sulfate-reducing strain NaphS2 [33]. In contrast, ctmEF is phylogenetically related to genes of the alphabacterial Caulobacter species. Ferredoxins and ferredoxin reductases are well known as electron transfer chain from the NADH/NADPH-pool to cytochrome $\mathrm{P} 450$ monooxygenases in aerobic bacteria [13]. Transposon mutants of $\operatorname{ctm} A, \operatorname{ctm} B$ or $\operatorname{ctm} E$ lacked the capability to mineralize the acyclic $\beta$-myrcene or the bicyclic $\alpha$-pinene. Thus, enzymes of the $c t m$ cluster may also be involved in the metabolism of these monoterpenes in C. defragrans 65Phen.

The oxidation of perillyl alcohol involved GeoA, previously identified as geraniol dehydrogenase with a broad substrate spectrum, and GeoB, previously identified as geranial dehydrogenase [26]. The in-frame deletion of geoB revealed in vivo the co-metabolic transformation of limonene to perillyl alcohol and further to perillyl aldehyde. Both GeoA and GeoB were highly expressed in cells grown on $\alpha$-phellandrene. Another aldehyde dehydrogenase gene (CDM24151) with unknown substrate specificity was also expressed in cells grown on $\alpha$-phellandrene, but the level of induction was lower than that of GeoB. The gene was located outside the monoterpene island and was related to an aldehyde dehydrogenase of Pusillimonas sp. T7-7 (84\% amino acid identity). The activation of perillic acid to a coenzyme A thioester may be catalyzed by the induced CDM26265, an ATP-dependent ligase that we annotated as $\mathrm{GeoC}$ due to the gene location next but one near geoA.

The ring cleavage of the cyclic perillyl-CoA resembles the cyclohex-1-ene-1-carboxyl-CoA degradation in anaerobic benzoate degraders or the described monocyclic monoterpene degradation pathways of Pseudomonas putida [34] or Geobacillus (ex. Bacillus) stearothermophilus [35] (Figure 3). We named the genes monoterpene ring cleavage-associated genes $(m r c)$. Perillyl-CoA may be hydrated by MrcF to 2-hydroxy-4-isopropenylcyclohexane-1-carboxyl-CoA. Oxidation by the dehydrogenase MrcD may yield 4-isopropenyl-2-oxocyclohexane-1carboxyl-CoA that may be hydrolysed by MrcE to 4isopropenylpimelyl-CoA. Related enzymes of the anaerobic benzoate catabolism, BadK, BadH and BadI, catalyze the $\beta$-oxidation-like oxidation of cyclohexenecarboxyl-CoA, forming pimelyl-CoA. Among the strains of Azoarcus and Thauera, the enzymes of Azoarcus sp. KH32C are most closely related to MrcDEF. BadK (YP_007598293) catalyzes 


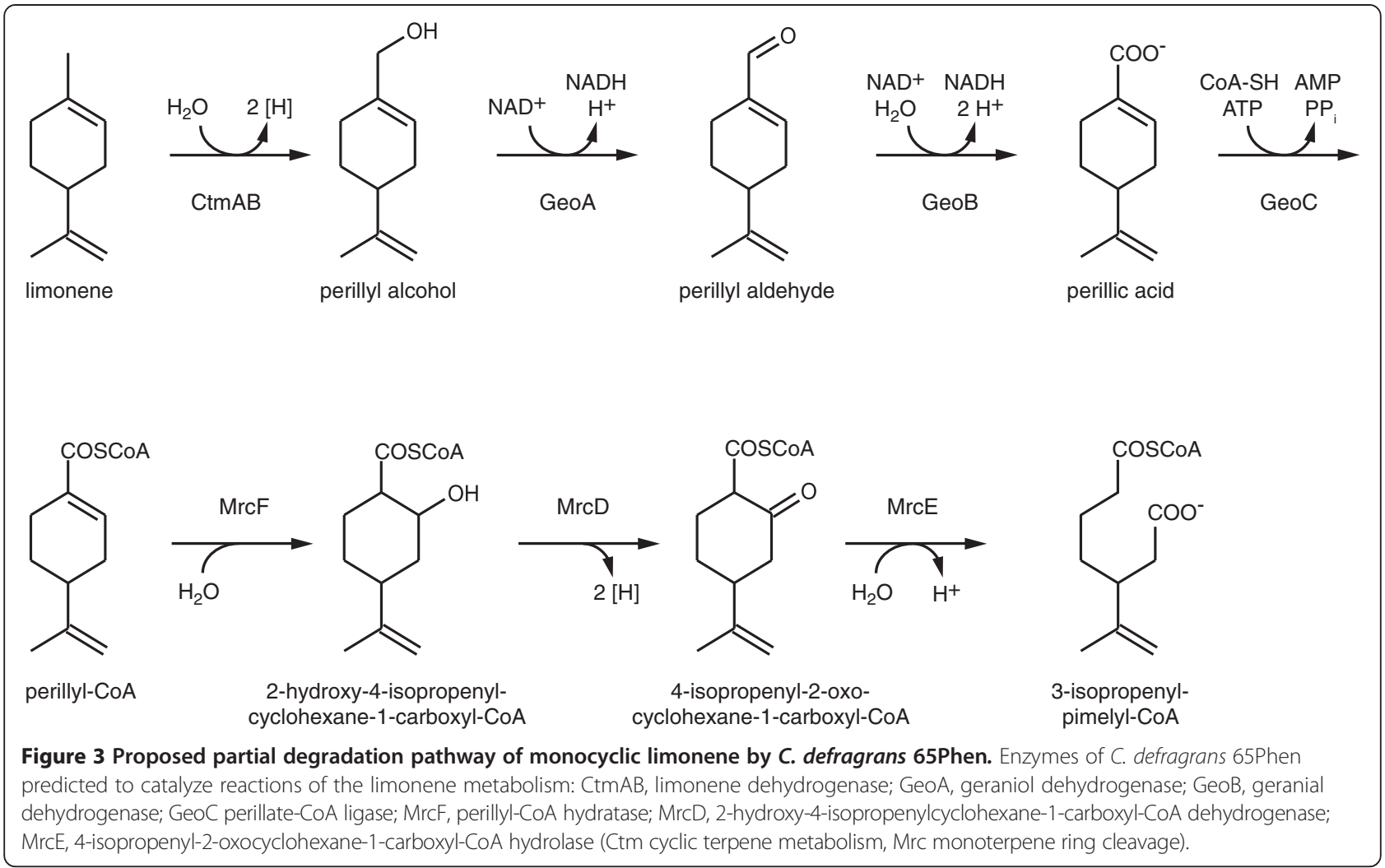

the hydration of cyclohex-1-ene-1-carboxyl-CoA and has an amino acid identity of $53 \%$ to MrcF, affiliating to the enoyl-CoA hydratase/isomerase superfamily. The dehydrogenase BadH (YP_007598295) has a high identity of 85\% to $\mathrm{MrcD}$. The formation of pimelyl-CoA is catalzyed by BadI (YP_007598294) which is highly similar to MrcE (88\% identity). All three proteins MrcDEF were expressed in cells grown on $\alpha$-phellandrene. In $C$. defragrans 65Phen, the genes required for ring cleavage are located in a cluster ( $m r c A B C D E F G H)$. An insertion mutant of $m r c F$ did not grow on monoterpenes like limonene or $\alpha$-phellandrene. A second mutant strain with an insertion in the gene $m r c C$ also lacked the capability to grow on limonene. $\mathrm{MrcC}$ was annotated as a 2,4-dienoyl reductase.

The following degradation of 4-isopropenylpimelylCoA may include 3 steps of $\beta$-oxidation-like degradation forming three acetyl-CoA and methacrylyl-CoA which may be decarboxylated in a valine-like degradation to propanoyl-CoA. Propanoyl-CoA is connected to the TCA cycle via the methylcitrate cycle. Several enzymes of the valine degradation were up-regulated, but enzymes of the methylcitrate cycle were detected without expression differences between the substrate conditions. However, transposon mutants in 2-methylcitrate synthase and 2methylcitrate dehydratase showed impaired growth on limonene. Genes assigned to the valine degradation and methylcitrate cycle were located outside of the genome island.

The complete genome of $C$. defragrans did not show the pathway for the utilization of acyclic monoterpenes as defined by the studies on citronellol in pseudomonads [5]. The $a t u$ and $l i u$ genes encode two pathways of enzymes required to transform geranyl-CoA to acetyl-CoA and acetoacetate. The liu genes representing the leucine degradation via 3-methylbut-2-enoyl-CoA were present in the genome of $C$. defragrans 65Phen, but the genes for the acyclic terpene utilization (atu) were not identified. Atu enzymes catalyze the carbon chain cleavage from an acyclic ten-carbon carboxyl-CoA ester to 3-methyl-crotonylCoA which is further degraded in the liu pathway to acetyl-CoA and acetoacetate. The tertiary carbon atom undergoes a carbon-carbon cleavage after carboxylation of the methyl group by AtuC/AtuF. Homologues to these pathway-specific genes $a t u C / a t u F$ were not present in the genome of $C$. defragrans. The absence of atu genes and the lack of growth on myrcene exhibited by transposon mutants of the limonene degradation pathway is first evidence for a connection between mycrene and limonene metabolism. Other initial reports on the biological formation of cyclic monoterpenes from myrcene [9] and linalool [36] are known, but the molecular basis for this reactions have not been revealed so far. 


\section{Conclusions}

The degradation of monocyclic monoterpenes in C. defragrans 65Phen is initiated at the methyl group via oxidation by a new enzyme belonging to the phytoene dehydrogenase family (Cog1233). Ferredoxin and ferredoxin reductase are involved in the oxidation of limonene to perillyl alcohol. Expressed proteins and transposon mutants indicate that the further degradation pathway is an oxidation to perillic acid, followed by activation to perillyl CoA thioester and a ring cleavage. Most of the genes for these pathways are located on a genetic island, named the monoterpene island, and seemed to be acquired by horizontal gene transfer from aerobic as well as from anaerobic bacteria.

\section{Methods}

\section{Bacterial strains, plasmids and culture conditions}

C. defragrans 65Phen-RIF, a strain containing a rifampicin resistance, was used in this study in synonym for $C$. defragrans 65Phen wild type [27]. Strains of $C$. defragrans and E. coli as well as plasmids used in this work are listed in Table 3. Additional transposon insertion mutants used in this study are listed in Table 2.

Preparation of anoxic mineral media and anaerobic cultivation was performed as previously described with small modifications [21]. Media were buffered with $10 \mathrm{mM} \mathrm{NaH}_{2} \mathrm{PO}_{4} \mathrm{pH}$ 7.2, vitamins were not added and the headspace consisted of $\mathrm{N}_{2}$ gas. Growth experiments were performed in $10 \mathrm{~mL}$ media and $300 \mu \mathrm{L} \mathrm{HMN}$. Inocula were $2 \%(\mathrm{v} / \mathrm{v})$ of a freshly grown culture. Cultures were incubated at $28^{\circ} \mathrm{C}$ and shaken at $90 \mathrm{rpm}$. The optical density was measured directly at $660 \mathrm{~nm}$. Monoterpenes used in this study were purchased from SigmaAldrich (Taufkirchen, Germany) with 95 to $97 \%$ purity.

\section{Metabolite analysis}

For metabolite analysis, triplicates of $C$. defragrans 65Phen cultures and non-inoculated controls were grown in $500 \mathrm{~mL}$ culture flask with $400 \mathrm{~mL}$ medium. The mineral medium was autoclaved in the flasks and the headspace was replaced with nitrogen immediately afterwards. After cooling to $21^{\circ} \mathrm{C}$, trace minerals, $20 \mathrm{~mL} H M N, 3 \mathrm{mM}$ monoterpenes (limonene, perillyl alcohol, perillyl aldehyde or perillic acid) and $0.5 \%$ inoculum were added. For each measurement $50 \mu \mathrm{L}$ of the $\mathrm{HMN}$ phase and $1 \mathrm{~mL}$ of the aqueous phase were sampled. In total, a maximum of $5 \%$ (v/v) of each phase was sampled. $1 \mu \mathrm{L}$ of the organic phase was analyzed by gas chromatography with flame ionization detection (PerkinElmer Auto System XL, Überlingen, Germany). Separation was performed on an Optima-5 column $(50 \mathrm{~m} \times 0.32 \mathrm{~mm}, 0.25 \mu \mathrm{m}$ film thickness; MachereyNagel, Düren, Germany) with the following temperature program: injection port temperature $250^{\circ} \mathrm{C}$, detection temperature $350^{\circ} \mathrm{C}$, initial column temperature $60^{\circ} \mathrm{C}$ for $3 \mathrm{~min}$, increasing to $120^{\circ} \mathrm{C}$ with a rate at $3^{\circ} \mathrm{C} \mathrm{min}^{-1}$, staying constant for $0.1 \mathrm{~min}$, further increasing to $320^{\circ} \mathrm{C}$ at $40^{\circ} \mathrm{C} \mathrm{m^{-1 }}$ and hold for $3 \mathrm{~min}$. The split ratio was set to 1:8. All concentrations refer to the aqueous phase. The sample of the aqueous phase was analyzed for optical density at $600 \mathrm{~nm}$ and for nitrate and nitrite concentrations as

Table 3 Bacterial strains and plasmids used in this work

\begin{tabular}{|c|c|c|}
\hline Strain or plasmid & Relevant characteristics & Source or reference \\
\hline \multicolumn{3}{|l|}{ Strains } \\
\hline C. defragrans & & [21] \\
\hline 65Phen-RIF & $\mathrm{Ra}^{\mathrm{R}}$ & [27] \\
\hline$\Delta g e o B$ & 65Phen-RIF, Ra ${ }^{R}, \Delta g e o B$ & This study \\
\hline ctmA::Tn5a & 65Phen-RIF, $\mathrm{Ra}^{\mathrm{R}}, \mathrm{Km}^{\mathrm{R}}$, transposon insertion in ctmA at position 133 & This study \\
\hline $\operatorname{ctm} A:: \operatorname{Tn} 5 b$ & 65Phen-RIF, $\mathrm{Ra}^{\mathrm{R}}, \mathrm{Km}^{\mathrm{R}}$, transposon insertion in $\mathrm{ctmA}$ at position 1188 & This study \\
\hline$c t m B:: \operatorname{Tn} 5 a$ & 65Phen-RIF, $\mathrm{Ra}^{\mathrm{R}}, \mathrm{Km}^{\mathrm{R}}$, transposon insertion in $\mathrm{ctm} B$ at position 38 & This study \\
\hline$c t m B:: \operatorname{Tn} 5 b$ & 65Phen-RIF, Ra ${ }^{R}, \mathrm{Km}^{\mathrm{R}}$, transposon insertion in $c t m B$ at position 559 & This study \\
\hline ctmE::Tn5 & 65Phen-RIF, $\mathrm{Ra}^{\mathrm{R}}, \mathrm{Km}^{\mathrm{R}}$, transposon insertion in ctmE at position 111 & This study \\
\hline \multicolumn{3}{|l|}{ E. coli } \\
\hline W20767 & $\begin{array}{l}\text { RP4-2-tet::Mu-1, kan::Tn7 integrant, leu-63::IS10, recA1, creC510, hsdR17, endA1, } \\
\text { zbf-5, uidA, (UMlul):: pir + thi }\end{array}$ & [37] \\
\hline S17-1 & Thi, pro, hsdR, recA with RP4-2[Tc::Mu-Km::Tn7] & [38] \\
\hline \multicolumn{3}{|l|}{ Plasmids } \\
\hline pRL27 & Tn5 with KmR, R6K ori, oriT, RP4, tnp & [31] \\
\hline pCR4-TOPO & $A m^{R}, \mathrm{Km}^{\mathrm{R}}, \mathrm{lacZa}$ & Invitrogen \\
\hline pK19mobsacB & $\mathrm{Km}^{\mathrm{R}}$, mob, sacB modified from B. subtilis, lacZa & [39] \\
\hline pK19mobsacB $4 g e o B$ & $\mathrm{Km}^{\mathrm{R}}$, mob, sacB modified from B. subtilis, lacZa, 2000b flanking regions of $\Delta g e o B$ & This study \\
\hline
\end{tabular}


described [19]. Organic acids were separated on a reverse phase HPLC with a Nucleodur C18 Isis column $(25 \mathrm{~cm} \times$ $4.6 \mathrm{~mm}, 5 \mu \mathrm{m}$ spheres; Macherey-Nagel, Düren, Germany). The mobile phase consisted of $36 \%(\mathrm{v} / \mathrm{v})$ acetonitrile and $64 \%(\mathrm{v} / \mathrm{v}) 0.05 \mathrm{M}$ ammonium acetate buffer $\mathrm{pH}$ 5.0. The flow rate was $0.8 \mathrm{~mL} \mathrm{~min}^{-1}$ and the effluent was monitored at $217 \mathrm{~nm}$ [40].

For additional metabolite analysis, cultures were prepared as described with $0.5 \%(\mathrm{v} / \mathrm{v})$ Tween 20 replacing the HMN phase. Both arrangements increase the availability of limonene for the cells. $20 \mathrm{mM}$ acetate was added as cosubstrate. To salt out metabolites, $5 \mathrm{~g} \mathrm{KCO}_{3}$ and $300 \mu \mathrm{l}$ isopropanol were added to $10 \mathrm{~mL}$ culture sampled at the early stationary growth phase. The organic and aqueous phases were separated via centrifugation at $5000 \times g$ for 5 min. $1 \mu \mathrm{L}$ of the upper phase was analyzed for metabolites and their enantiomer-specificity using a gas chromatograph (PerkinElmer Auto System XL; Überlingen, Germany) equipped with a flame ionization detector. Separation was accomplished on a Hydrodex- $\beta-6$ TBDM column $(25 \mathrm{~m} \times 0.25 \mathrm{~mm}$; Macherey-Nagel, Düren, Germany) by the following temperature program: injection temperature $200^{\circ} \mathrm{C}$; detection temperature $230^{\circ} \mathrm{C}$, initial column temperature $80^{\circ} \mathrm{C}$ for $1 \mathrm{~min}$, increasing to $130^{\circ} \mathrm{C}$ at a rate of $5^{\circ} \mathrm{C} \mathrm{min}^{-1}$, after $0.5 \mathrm{~min}$ further increasing to $230^{\circ} \mathrm{C}$ at $20^{\circ} \mathrm{C} \mathrm{min}^{-1}$ and stationary for $2 \mathrm{~min}$. For identification of peaks, a $1 \mu \mathrm{l}$ sample was analyzed on a Trace GC/MS (Thermo Finnigan, Waltham, USA). Separation was performed on a HP-5 column $(25 \mathrm{~m} \times 0.2 \mathrm{~mm} \times$ $0.33 \mu \mathrm{m}$; Agilent, Santa Clara, USA) with the following temperature program: injection port temperature $250^{\circ} \mathrm{C}$, initial column temperature $60^{\circ} \mathrm{C}$ for $6 \mathrm{~min}$, increasing to $120^{\circ} \mathrm{C}$ at $3^{\circ} \mathrm{C} \mathrm{min}{ }^{-1}$ further to $320^{\circ} \mathrm{C}$ at $40^{\circ} \mathrm{C} \mathrm{min}^{-1}$ and hold for $3 \mathrm{~min}$.

\section{Genome sequencing and annotation}

Genomic DNA was extracted as previously described [41]. The genome of Castellaniella defragrans 65Phen was sequenced at the Max Planck Genome Center in Cologne, using the PacBio SMRT system (Pacific Biosciences, Menlo Park, CA). 19858 quality-checked error-corrected reads with at least 4975 bases were de novo assembled to a single contig. The average coverage amounted 91 times and around $4 \mathrm{~kb}$ overlapped at each end. Open-reading frames were predicted and annotated by the Rapid Annotations using Subsystems Technology (RAST) pipeline [42]. The $\mathrm{G}+\mathrm{C}$ content was calculated using Artemis [43]. Putative prokaryotic promoters were predicted with BPROM (http://www. softberry.com/berry.phtml?topic=bprom\&group=programs \&subgroup $=$ gfindb) and putative terminators were identified using WebGeSTer [44]. ANI was calculated according to Goris et al. [45]. The complete genome sequence of Castellaniella defragrans 65Phen has been deposited at GenBank under the accession number HG916765.

\section{Label-free quantitative proteome analysis}

The soluble and membrane protein enriched proteome of cells grown on acetate and $\alpha$-phellandrene were compared by 2D-SDS-PAGE and LC-ESI-MS/MS. The cyclic monoterpene $\alpha$-phellandrene was used as monoterpene growth substrate because of its origin as enrichment substrate for Castellaniella defragrans 65Phen. Anaerobic cultures were grown in a $10 \mathrm{~L}$ fermenter with $100 \mathrm{mM}$ nitrate and $10 \mathrm{mM} \alpha$-phellandrene or $50 \mathrm{mM}$ acetate as previously described [23].

For analyzing the soluble protein fraction, cells were disrupted by sonication in lysis buffer $(10 \mathrm{mM}$ Tris $\mathrm{pH}$ 7.5, 10 mM EDTA pH 8.0) containing $1.7 \mathrm{mM}$ phenylmethanesulfonylfluoride (PMSF) and cell debris was removed by centrifugation. Proteins $(80 \mu \mathrm{g})$ were separated on 2D SDS-polyacrylamide gels according to their isoelectric point in the $\mathrm{pH}$ range of 3 to 10 and to their molecular mass. Proteins were stained with the fluorescence Sypro Ruby protein gel stain (Invitrogen, Darmstadt, Germany). Spots were detected and quantified on gel images using the software Delta2D (Decodon, Greifswald, Germany). Biological triplicates of each condition were fused and overlaid as dual-channel images and individual spot volumes $(\% \mathrm{Vol})$ were calculated as proportion of all proteins on the gel images. Spot ratios which represent an at least 2.5-fold change in spot volume, compared to spots of the acetate samples, were considered. All dominant spots and such spots with ratios $>2.5$ were automatically excised from the gel (Ettan Spo Picker, GE Healthcare), digested with trypsin and spotted onto a matrix-assisted laser desorption/ionization (MALDI)-target (Ettan Spot Handling Workstation, GE Healthcare). High-throughput MALDI-TOF measurements combined with tandem mass spectrometry were performed on a 4800 MALDI-TOF/ TOF Analyser (Applied Biosystems, Darmstadt, Germany). Spectra of a mass range from 900 to $3700 \mathrm{Da}$ were detected during the MALDI-TOF analysis. The three strongest peaks were recorded by the MS/MS analysis. With the GPS Explorer Software (Applied Biosystems) Version 3.6, peaks were indexed and assigned to the corresponding amino acid sequences in the $C$. defragrans 65Phen database by the Mascot search engine Version 2.1.04 (Matrix Science Ltd, Boston, MA, USA). Proteins of at least 25\% sequence coverage, minimum 2 unique assigned peptides and a Mowse score value of 75 or higher were treated as identified.

To analyze the membrane protein-enriched fraction, cells were disrupted with lysis buffer (50 mM Tris $\mathrm{pH} 7.5$, $1 \mathrm{mM}$ PMSF) by sonication. Cell debris was removed by short centrifugation and membranes were pelleted by additional ultracentrifugation $\left(100,000 \times g, 1 \mathrm{~h}, 4^{\circ} \mathrm{C}\right)$. Following the protocol established by Eymann et al. [46], the protein pellet was homogenized and washed in high-salt buffer (20 mM Tris $\mathrm{pH}$ 7.5, $1 \mathrm{M} \mathrm{NaCl}$ ), alkaline buffer 
(0.1 $\left.\mathrm{M} \mathrm{Na}_{2} \mathrm{CO}_{3}-\mathrm{HCl} \mathrm{pH} 11,0.1 \mathrm{M} \mathrm{NaCl}\right)$ and $50 \mathrm{mM}$ triethylammonium bicarbonate (TEAB) buffer $(\mathrm{pH} 7.8)$ with ultracentrifugation $\left(100,000 \times g, 1 \mathrm{~h}, 4^{\circ} \mathrm{C}\right)$ after each washing step. The final pellet was resolved in $50 \mathrm{mM}$ TEAB buffer. Samples of $15 \mu \mathrm{g}$ protein were separated by 1D SDS-PAGE in two technical replicates per condition. After staining with Coomassie Brilliant Blue, each gel lane was divided into 10 slices which were excised and individually analyzed. Proteins were in gel-digested with trypsin, separated by reverse phase chromatography using a nano-Acquity UPLC System (Waters, Milford, MA, USA) and analyzed by MS/MS in a LTQ-Orbitrap mass spectrometer (Thermo Fisher Scientific, Waltham, MA, USA). Spectra were assigned to the corresponding amino acid sequence of the $C$. defragrans 65Phen database using Sorcerer-SEQUEST (SEQUEST version 2.7 revision 11, Thermo Scientific) including Scaffold 3_00_08 (Proteome Software Inc., Portland, OR, USA). SEQUEST was searched with a parent ion tolerance of $10 \mathrm{ppm}$ and a fragment ion mass tolerance of 1.00 Da. For protein identification, a stringent SEQUEST filter for peptides was used (Xcorr versus charge state: 1.80 for singly, 2.2 for doubly, and 3.3 for triply charged ions and deltaCn value greater than 0.10 ) and at least two unique peptides per proteins were required for identification. Protein fractions from both conditions were considered to be different if no peptides were detected in the alternative fraction or if a significant difference was shown by the Scaffold internal $t$-test analysis (threshold of 95\%).

For continuity of the protein abbreviations, $\mathrm{GeDH}$ and $\mathrm{GaDH}[26]$ were renamed to GeoA and GeoB according to their gene abbreviations.

\section{Deletion mutagenesis}

An in frame deletion mutant of $g e o B$ was created as described for the ldi gene [27]. The 5'-flanking region (2015 bases) was amplified with the primers GeoB1_X baI_F (tctagaagagatcgtgaccagctttcc) and GeoB2_NdeI_R (catatgcatcgagggtgtctcctgagt) and the 3'-flanking region (1967 bases) with GeoB3_NdeI_F (catatgtaggatggacggac accagg) and GeoB4_HindIII_R (aagcttgatgccgacggcgaa cttg). Both amplicons were ligated in a pK19mobsacB plasmid via subcloning using a pCR4-TOPO vector (Invitrogen, Darmstadt, Germany). The constructed plasmid pK19mobsacB $\triangle$ geo $B$ was transferred in $C$. defragrans 65 Phen by conjugation and colonies were screened for a second recombination event.

\section{Transposon insertion mutagenesis}

Transposon insertion mutants of $C$. defragrans 65Phen were created by biparental conjugation. $2 \mathrm{~mL}$ of overnight cultures of $C$. defragrans 65Phen anaerobically grown on $20 \mathrm{mM}$ acetate and $20 \mathrm{mM}$ nitrate with $150 \mu \mathrm{g} \mathrm{mL}^{-1}$ rifampicin and of E.coli W20767 (lysogeny broth medium with $50 \mu \mathrm{g} \mathrm{mL} \mathrm{m}^{-1}$ kanamycin) carrying the plasmid pRL27 were spin down at $8000 \times g$ for $5 \mathrm{~min}$. The pellets were washed twice and resuspended in $100 \mu \mathrm{L}$ mineral medium. The optical density at $600 \mathrm{~nm}$ of both cell suspensions was adjusted to 1 , combined equally $(100 \mu \mathrm{L})$ and added as one drop on a mineral medium plate $(1.5 \%$ agar) containing $50 \mathrm{mM}$ acetate without antibiotics. After $24 \mathrm{~h}$ incubation at $28^{\circ} \mathrm{C}$, cells were resuspended from the plate with $1 \mathrm{~mL}$ mineral medium. $100 \mu \mathrm{L}$ of cell suspension were plated in different dilutions on mineral medium agar plates containing $50 \mathrm{mM}$ acetate, $25 \mu \mathrm{g} \mathrm{mL}^{-1}$ kanamycin and $150 \mu \mathrm{g} \mathrm{mL}^{-1}$ rifampicin. The plates were anaerobically incubated in a jar for 4 days at $28^{\circ} \mathrm{C}$. Mutants affected in the limonene metabolism were identified by replica plating (replicator stamp, Carl Roth $\mathrm{GmbH}+\mathrm{Co}$. KG, Karlsruhe, Germany). The replicon was incubated in an anaerobic jar with a limonene-enriched headspace for at least two days. Putative mutant colonies were transferred twice to new plates with acetate or limonene as carbon source to confirm the phenotype and the insertion position was determined by a direct sequencing approach. The genomic DNA was isolated from a liquid culture using FastDNA Spin Kit for Soil (MP Biomedicals, OH, USA). 2 to $3 \mu \mathrm{g}$ genomic DNA were applied for the sequencing PCR reaction using BigDye Terminator v3.1 Cycle Sequencing Kit (Applied Biosystems, Life Technologies Corporation, Carlsbad, CA, USA). The primers tpnRL 17-1 and tpnRL 13-2 [31] were used with following program: $95^{\circ} \mathrm{C}$ for $5 \mathrm{~min}, 100$ cycles of $96^{\circ} \mathrm{C}$ for $30 \mathrm{sec}, 52^{\circ} \mathrm{C}$ for $20 \mathrm{sec}$ and $60^{\circ} \mathrm{C}$ for $4 \mathrm{~min}$. The fragments were sequenced with an ABI Prism 3130xl Genetic Analyzer (Applied Biosystems Life Technologies Corporation, Carlsbad, CA, USA).

\section{Additional files}

\begin{abstract}
Additional file 1: Table S1. Up-regulated proteins of cells grown with a-phellandrene. ${ }^{\mathrm{a}}$ 2D, identified with 2D-SDS-PAGE and MALDI-TOF-MS; LC, identified with LC-ESI-MS/MS. ${ }^{b}++$ peptides only identified in a-phellandrene fraction, + increase in a-phellandrene fraction, 0 ratio remained unchanged.

Additional file 2: Figure S1. Growth of $C$. defragrans 65Phen transposon mutants. $(\bullet)$ C. defragrans 65Phen wild type, ( $\nabla)$ ctmA::Tn5a,

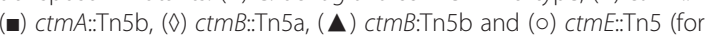
details see Tabl. 3) in anoxic incubations with $3 \mathrm{mM}$ limonene (A) and $3 \mathrm{mM}$ perillyl alcohol (B) as well as oxic incubations with $3 \mathrm{mM}$ limonene (C) and $3 \mathrm{mM}$ perillyl alcohol (D) are represented.
\end{abstract}

Competing interests

The authors declare that they have no competing interests.

Authors' contributions

$J H$ and JP planed the study. EMD performed the transposon insertion mutagenesis. SM, DB and RS supported the proteome analysis. BH and RR sequenced the genome of Castellaniella defragrans 65Phen. JP analyzed the genome and proteome, created the deletion mutant of geoB, did physiological experiments and metabolite identification. JP and JH analyzed 
the data and wrote the manuscript. All authors read and approved the final manuscript.

\section{Acknowledgments}

We thank Sarah Moser for measuring the optical density of cultures. Christoph König kindly provided assistance in the genome sequencing. This study was financed by the Max Planck Society.

\section{Author details}

'Department of Microbiology, Max Planck Institute for Marine Microbiology, Celsiusstraße 1, Bremen D-28359, Germany. ${ }^{2}$ Institute of Marine Biotechnology, Greifswald, Germany. ${ }^{3}$ Max Planck Genome Centre Cologne, Cologne, Germany. ${ }^{4}$ Department of Pharmaceutical Biotechnology, Ernst-Moritz-Arndt-University, Greifswald, Germany. ${ }^{5}$ Department of Microbiology, Ernst-Moritz-Arndt-University, Greifswald, Germany.

Received: 14 February 2014 Accepted: 12 June 2014

Published: 21 June 2014

\section{References}

1. Kesselmeier J, Staudt M: Biogenic volatile organic compounds (VOC): an overview on emission, physiology and ecology. J Atmos Chem 1999, 33:23-88.

2. Turek C, Stintzing FC: Stability of essential oils: a review. Compr Rev Food Sci Food Saf 2013, 12:40-53.

3. Schrader J: Microbial flavour production. In Flavours and Fragrances: Chemistry, Bioprocessing and Sustainability. 1st edition. Edited by Berger RG. Springer-Verlag New York: LLC; 2007.

4. Dhavalik RS, Bhattach PK: Fermentation of limonene by a soil pseudomonad. Indian J Biochem 1966, 3:144-157.

5. Forster-Fromme $\mathrm{K}$, Jendrossek D: Identification and characterization of the acyclic terpene utilization gene cluster of Pseudomonas citronellolis. FEMS Microbiol Lett 2006, 264:220-225.

6. Bhattacharyya PK, Prema BR, Kulkarni BD, Pradhan SK: Microbiological transformation of terpenes - hydroxylation of alpha-pinene. Nature 1960 187:689-690.

7. Lehnert N, Krings U, Sydes D, Wittig M, Berger RG: Bioconversion of car-3-ene by a dioxygenase of Pleurotus sapidus. J Biotechnol 2012, 159:329-335.

8. Gibbon GH, Pirt SJ: The degradation of alpha-pinene by Pseudomonas PX1. FEBS Lett 1971, 18:103-105.

9. Esmaeili A, Tavassoli A: Microbial transformation of citral by Penicillium sp. Acta Biochim Pol 2010, 57:265-268.

10. Geron C, Rasmussen R, Arnts RR, Guenther A: A review and synthesis of monoterpene speciation from forests in the United States. Atmos Environ 2000, 34:1761-1781.

11. Maróstica MR, Pastore GM: Biotransformation of limonene: a review of the main methabolic pathways. Quim Nova 2007, 30:382-387.

12. Molina G, Pimentel MR, Pastore GM: Pseudomonas: a promising biocatalyst for the bioconversion of terpenes. Appl Microbiol Biotechnol 2013, 97:1851-1864

13. Schewe H, Mirata MA, Holtmann D, Schrader J: Biooxidation of monoterpenes with bacterial monooxygenases. Process Biochem 2011, 46:1885-1899.

14. Bicas $J \mathrm{~L}$, Fontanille $\mathrm{P}$, Pastore $\mathrm{GM}$, Larroche $\mathrm{C}$ : Characterization of monoterpene biotransformation in two pseudomonads. J Appl Microbiol 2008, 105:1991-2001.

15. Bicas JL, Fontanille P, Pastore GM, Larroche C: A bioprocess for the production of high concentrations of R-(+)-alpha-terpineol from R-(+)-limonene. Process Biochem 2010, 45:481-486.

16. Cadwallader KR, Braddock RJ, Parish ME, Higgins DP: Bioconversion of (+)-limonene by Pseudomonas gladioli. J Food Sci 1989, 54:1241-1245.

17. Savithiry N, Cheong TK, Oriel P: Production of alpha-terpineol from Escherichia coli cells expressing thermostable limonene hydratase. Appl Biochem Biotechnol 1997, 63-65:213-220.

18. Tadasa K: Intermediates in bacterial-degradation pathway of alpha-terpineol. Agric Biol Chem 1977, 41:2095-2096.

19. Harder J, Probian C: Microbial-degradation of monoterpenes in the absence of molecular-oxygen. Appl Environ Microbiol 1995, 61:3804-3808.

20. Foss S, Harder J: Thauera linaloolentis sp. nov. and Thauera terpenica sp. nov., isolated on oxygen-containing monoterpenes (linalool, menthol, and eucalyptol) nitrate. Syst Appl Microbiol 1998, 21:365-373.
21. Foss $\mathrm{S}$, Heyen $U$, Harder J: Alcaligenes defragrans sp. nov., description of four strains isolated on alkenoic monoterpenes ((+)-menthene, alpha-pinene, 2-carene, and alpha-phellandrene) and nitrate. Syst Appl Microbiol 1998, 21:237-244.

22. Heyen U, Harder J: Cometabolic isoterpinolene formation from isolimonene by denitrifying Alcaligenes defragrans. FEMS Microbiol Lett 1998, 169:67-71

23. Heyen U, Harder J: Geranic acid formation, an initial reaction of anaerobic monoterpene metabolism in denitrifying Alcaligenes defragrans. Appl Environ Microbiol 2000, 66:3004-3009.

24. Brodkorb D, Gottschall M, Marmulla R, Lüddeke F, Harder J: Linalool dehydratase-isomerase, a bifunctional enzyme in the anaerobic degradation of monoterpenes. J Biol Chem 2010, 285:30436-30442.

25. Lüddeke F, Harder J: Enantiospecific (S)-(+)-linalool formation from beta-myrcene by linalool dehydratase-isomerase. Z Naturforsch C 2011, 66:409-412

26. Lüddeke F, Wulfing A, Timke M, Germer F, Weber J, Dikfidan A, Rahnfeld T, Linder D, Meyerdierks A, Harder J: Geraniol and geranial dehydrogenases induced in anaerobic monoterpene degradation by Castellaniella defragrans. Appl Environ Microbiol 2012, 78:2128-2136.

27. Lüddeke F, Dikfidan A, Harder J: Physiology of deletion mutants in the anaerobic beta-myrcene degradation pathway in Castellaniella defragrans. BMC Microbiol 2012, 12:192.

28. Eaton RW: Dehydration of the off-flavor chemical 2-methylisoborneol by the R-limonene-degrading bacteria Pseudomonas sp. strain 19-rlim and Sphingomonas sp. strain BIR2-rlima. Biodegradation 2012, 23:253-261.

29. Fuchs $\mathrm{G}$, Boll M, Heider J: Microbial degradation of aromatic compounds from one strategy to four. Nat Rev Microbiol 2011, 9:803-816.

30. Palleroni NJ, Pieper DH, Moore ERB: Microbiology of hydrocarbon-degrading Pseudomonas. In Handbook of Hydrocarbon and Lipid Microbiology. Edited by Kenneth NT. Berlin Heidelberg: Springer; 2010:1787-1798.

31. Larsen RA, Wilson MM, Guss AM, Metcalf WW: Genetic analysis of pigment biosynthesis in Xanthobacter autotrophicus Py2 using a new, highly efficient transposon mutagenesis system that is functional in a wide variety of bacteria. Arch Microbiol 2002, 178:193-201.

32. Raisig A, Bartley G, Scolnik P, Sandmann G: Purification in an active state and properties of the 3-step phytoene desaturase from Rhodobacter capsulatus overexpressed in Escherichia coli. J Biochem 1996, 119:559-564.

33. Galushko A, Minz D, Schink B, Widdel F: Anaerobic degradation of naphthalene by a pure culture of a novel type of marine sulphate-reducing bacterium. Environ Microbiol 1999, 1:415-420.

34. Speelmans G, Bijlsma A, Eggink G: Limonene bioconversion to high concentrations of a single and stable product, perillic acid, by a solvent-resistant Pseudomonas putida strain. Appl Microbiol Biotechnol 1998, 50:538-544.

35. Chang HC, Gage DA, Oriel PJ: Cloning and expression of a limonene degradation pathway from Bacillus stearothermophilus in Escherichia coli. J Food Sci 1995, 60:551-553.

36. Devi JR, Bhattacharyya PK: Fermentation of geraniol, nerol and limonene by a soil pseudomonad, Pseudomonas incognita (linalool strain). Indian J Biochem Biophys 1977, 14:288-291.

37. Metcalf WW, Jiang WH, Daniels LL, Kim SK, Haldimann A, Wanner BL: Conditionally replicative and conjugative plasmids carrying lacZ alpha for cloning, mutagenesis, and allele replacement in bacteria. Plasmid 1996, 35:1-13

38. Simon R, Priefer U, Puhler A: A broad host range mobilization system for in vivo genetic-engineering - transposon mutagenesis in gram-negative bacteria. Bio Technol 1983, 1:784-791.

39. Schäfer A, Tauch A, Jager W, Kalinowski J, Thierbach G, Puhler A: Small mobilizable multipurpose cloning vectors derived from the Escherichia coli plasmids pK18 and pK19 - selection of defined deletions in the chromosome of Corynebacterium glutamicum. Gene 1994, 145:69-73.

40. Ezennia El, Phillips LR, Wolfe TL, Tabibi SE: Analysis of perillic acid in plasma by reversed-phase high-performance liquid chromatography with ultraviolet detection. J Chromatogr B 1997, 688:354-358.

41. Boström KH, Simu K, Hagström A, Riemann L: Optimization of DNA extraction for quantitative marine bacterioplankton community analysis. Limnol Oceanogr Meth 2004, 2:365-373.

42. Aziz RK, Bartels D, Best AA, DeJongh M, Disz T, Edwards RA, Formsma K, Gerdes S, Glass EM, Kubal M, Meyer F, Olsen GJ, Olsen R, Osterman AL, Overbeek RA, McNeil LK, Paarmann D, Paczian T, Parrello B, Pusch GD, 
Reich C, Stevens R, Vassieva O, Vonstein V, Wilke A, Zagnitko O: The RAST server: rapid annotations using subsystems technology. BMC Genomics 2008, 9:75.

43. Rutherford K, Parkhill J, Crook J, Horsnell T, Rice P, Rajandream MA, Barrell B: Artemis: sequence visualization and annotation. Bioinformatics 2000, 16:944-945.

44. Mitra A, Kesarwani AK, Pal D, Nagaraja V: WebGeSTer DB-a transcription terminator database. Nucleic Acids Res 2011, 39:D129-D135.

45. Goris J, Konstantinidis KT, Klappenbach JA, Coenye T, Vandamme P, Tiedje JM: DNA-DNA hybridization values and their relationship to whole-genome sequence similarities. Int I Syst Evol Microbiol 2007, 57:81-91.

46. Eymann C, Dreisbach A, Albrecht D, Bernhardt J, Becher D, Gentner S, Tam LT, Buttner K, Buurman G, Scharf C, Venz S, Völker U, Hecker M: A comprehensive proteome map of growing Bacillus subtilis cells. Proteomics 2004, 4:2849-2876.

doi:10.1186/1471-2180-14-164

Cite this article as: Petasch et al:: The oxygen-independent metabolism of cyclic monoterpenes in Castellaniella defragrans 65Phen. BMC Microbiology 2014 14:164

\section{Submit your next manuscript to BioMed Central and take full advantage of:}

- Convenient online submission

- Thorough peer review

- No space constraints or color figure charges

- Immediate publication on acceptance

- Inclusion in PubMed, CAS, Scopus and Google Scholar

- Research which is freely available for redistribution 